\title{
EMISSIONS FROM LANDFILL FIRES AND FIRES IN STORAGE OF WASTE
}

\author{
Anders Lönnermark \\ SP Technical Research Institute of Sweden
}

\begin{abstract}
Recent restrictions regarding landfills and handling of waste, have led to a new storage situation for a number of different types of storages of waste, ranging from existing landfills to temporary storages. This also means that new fire risks have evolved. The fires mean several different problems: economic losses, stop in operation (which in addition to economic effects can affect other parties), risk for fire spread to other premises, etc. Other important issues are health and environmental effects of waste fires.

In this paper, a number of fires and fire tests involving different types of stored waste are presented and discussed. Measured or estimated yields of emissions are presented and compared. A series of fire tests involving electrical and electronics waste (EE waste) and used tyres, performed in varied configurations, is described in more detail with example of results from gas analysis and analysis of runoff water. Clearly, as restrictions on emissions from controlled combustion are regulated and reduced, emissions from fires will become increasingly important from an environmental point of view.
\end{abstract}

\section{KEYWORDS}

Emissions; Fire; Landfill; Storage; Experiment; Gas analysis; PAH; PCDD/PCDF; Runoff water.

\section{INTRODUCTION}

Currently, significant change is occurring in the field of waste handling in Europe. According to EC 1999/31/EC [1] there are restrictions on the type of waste that can be accepted in a landfill. National strategies should also be developed to ensure that the amount of biodegradable municipal waste going to landfills is reduced. In Sweden, sorted combustible waste (after 1 January 2002) and organic waste (after 1 January 2005) are not allowed to be disposed at landfills [2].

This has led to a situation where a number of different types of waste depots exist, ranging from the existing landfills to temporary storages. This also means that new fire risks have evolved. One recent fire in sorted waste is the fire at CemMiljø A/S in Denmark in 2005 [3]. This fire, in mainly baled sorted waste, was very intense with $40 \mathrm{~m}$ high flames. After four days the fire was extinguished, by covering the burning waste with a mixture of wet clay, chalk, and soil. During two to three weeks after extinguishment, smoke could still be seen emitting from the area. Such fires cause several different problems: economic losses, stop in operation (which in addition to economic effects can affect other parties), risk for fire spread to other premises, etc. Other important issues are health and environmental effects. The smoke from this type of fire can contain a large number of hazardous species and can be 
Kalmar ECO-TECH '07

KALMAR, SWEDEN, November 26-28, 2007

transported a long distance from the origin of the fire. This paper focuses on the emissions from different types of waste.

\section{EXPERIENCES FROM REAL FIRES AND FIRE TESTS}

When studying emissions from fires the objective is to learn as much as possible about similar conditions during a real fire. However, there are several problems and limitations associated with analysing emissions in connections with real fires. These problems may include timing issues and availability of equipment. It can be questions of how representative the sampling is and there is a patent lack of knowledge on what is actually burning and how rapidly. Weather conditions such as wind and rain can also influence the results. However, one can still learn a great deal from analyses of emissions from real fire. In some cases a better way to obtain quantitative data is to perform controlled fire experiments. Emissions from both real fires and laboratory fires are included in this section. The presentation of emissions from fires will start with more traditional landfill fires to later focus more on fires in temporary waste depots.

Pettersson et al. have shown that the emissions of most species considered by them are higher from surface fires than from deep-seated fires, both given in actual concentration and given per ton of waste [4]. One reason for the lower emissions from deep-seated fires could be the long route of transportation through the fuel and the cooling effect leading to condensation of heavy gaseous species. In a simulated deep-seated landfill fire with $35000 \mathrm{~m}^{3}$ of waste, the highest concentrations of PCDD/PCDF was found to be $1-3 \mathrm{~m}$ above the seat of the fire [5].

The total emissions could, however, be higher from a deep-seated fire compared to a surface fire due to the difficulties in extinguishing a deep-seated fire and the resulting long burning times. In total Pettersson et al. performed measurement at one real deep-seated fire and three surface fires which were ignited for the purpose of investigation. Analyses of smoke from the deep-seated fire together with observations of the extension of the smoke plume were used to estimate the total emissions. It was estimated that 2500 tons of waste was burnt during one month. In comparison, it was estimated that during the first two surface fires 20 tons each was consumed, while in the third surface fire 22 tons of waste was consumed. The calculated yield (amount of a produced species divided by the total amount of consumed fuel) of emissions were $0.5-1.5 \mathrm{~g}$ chlorobenzenes /ton waste, 3.5-7.5 $\mu \mathrm{g} /$ ton dioxins (toxic equivalent, EADON), and 1.5-3.5 mg/ton PCB (sum of 7 individual PCBs: \#28, \#52, \#101, \#118, \#153, \#138, \#180). The corresponding values from three surface fire tests were $0.1-1.5 \mathrm{~g} /$ ton chlorobenzenes, 50 $900 \mu \mathrm{g} /$ ton dioxins (toxic equivalent, EADON), and 10-40 mg/ton PCB. This means that the yield of PCDD/PCDF and PCB were higher for the surface fires.

Gas analysis was performed in connection with fire tests conducted using $7.5 \mathrm{~m}^{3}$ nine month old waste in a $9 \mathrm{~m}^{3}$ container [6]. Both deep-seated fires and surface fires were simulated. Three tests of each type were reported. For chlorobenzenes the results varied between $5.5 \mathrm{~g} /$ ton and $5.9 \mathrm{~g} /$ ton for deep-seated fires and between $2.2 \mathrm{~g} /$ ton and $15 \mathrm{~g} /$ ton for surface fires. The corresponding values for TCDD toxic equivalents were 0.6-1.5 mg/ton for deepseated fires and $0.3-2.6 \mathrm{mg} / \mathrm{ton}$ for surface fires. This means that the yield of chlorobenzenes and dioxins were higher in the container tests than in the fire and tests presented by Pettersson et al.

During fire tests with domestic waste in $1 \mathrm{~m}^{3}$-scale, simulating deep-seated fires, the fire gases, run-off water, and fire debris were analysed for PCDD/PCDF, PAH, hexachlorobenzene, PCB, and metals [7]. The yield of PCDD/PCDF (expressed as TCDD I- 
TEQ varied between 10 and $440 \mathrm{ng} / \mathrm{kg}$, depending on test situation. This means that the results from these tests ranged over almost the entire span of the fires reported by Pettersson et al. For PCB (sum of the same 7 individual PCBs) the yields were $14-140 \mu \mathrm{g} / \mathrm{kg}$. The results correspond well with the large scale test, but once again cover a large range including the surface fire tests.

The concentration of PCDD/PCDF (TCDD I-TEQ) in the fire debris were analysed at two different positions: near the ignition source and further up in the waste. Near the point of ignition, the concentration varied between $6 \mathrm{ng} / \mathrm{kg}$ and $70 \mathrm{ng} / \mathrm{kg}$ (dry sample). The concentration $45 \mathrm{~cm}$ higher up in the waste was lower $(0.8-14 \mathrm{ng} / \mathrm{kg})$.

Other series of fire tests have been performed with waste where gas concentrations have been measured and presented. Nammari et al. studied baled domestic waste where two bales ( 800 $1000 \mathrm{~kg}$ each) were placed in a covered $30 \mathrm{~m}^{3}$ container [8]. The gas concentration were analysed in the exhaust from the container. High concentrations of total PAHs, PCDD/PCDF, and some heavy metals were reported. Other examples where gas concentrations were analysed are simulated landfill fires [9] and combustion of domestic waste in barrels [10-13]. Since most of the results discussed in this paper are presented as yields, these concentrations are not further discussed.

Between 2000 - 2003 the Swedish Geotechnical Institute (SGI) and several Local Councils conducted a project focused on the analysis of the environmental effects of a variety of accidents [14-16], on behalf of the Swedish Rescue Services Agency (SRV). Samples were taken mainly in conjunction with major fires. Results have been presented for a total of 23 incidents. All but one of these incidents was a fire (the exception was a tanker which released diesel fuel). In Figure 1 the distribution between different types of incidents is presented. As can be seen from the figure almost half of the selected fires of interest were fires in landfills or storages. This indicates the importance of this type of fire.

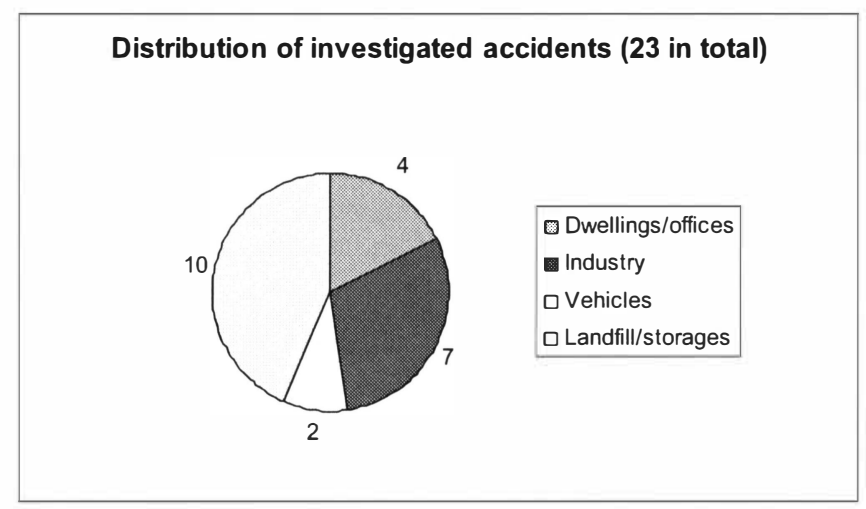

Figure 1. Distribution of types of accidents invested in the project analysing environmental effects of a variety of accident. 
It proved to be difficult to analyse the emissions to air in most of the cases and therefore the conclusions mainly regard the runoff water. One conclusion that can be made based on the samples and analyses is that PAH is generally an important problem in run-off water from fire extinguishment activities. Similarly, the run-off water is also associated with VOC-species in most fires. Brominated flame retardants were mainly present in run-off water from fire in electronic waste. In conjunction with a container fire a large number of different organic species were found, including a high bromine content. Another conclusion is that a large range of metals were present in high concentrations in many of the samples analysed.

Since tyres are no longer allowed to be deposited in landfills, tyres can now be stored in many different locations, at retailers and workshops, in large storages waiting to be cut into smaller pieces and to be disposed of, e.g. by combustion. These storages sites pose severe fire risks. Such fires are difficult to extinguish, both due to the large energy content and due to the geometry. Some fires have involved a very large number of tyres, e.g. Rhinehart (1983) and Westley (1999) in the USA and Hagersville and Saint Amable (1990) in Canada.

From descriptions of several tyre fires, information on measured and estimated emissions to air and water, and fall-out onto the ground, can be found [17-21]. How detailed this information is varies significantly. The purpose of most of these measurements has been to determine whether the smoke poses a danger for workers or habitants in the neighbourhood of the fire. Therefore mainly concentration measurements are reported. These results are, however, often difficult to use for estimates or calculations of the total emissions, etc, since they are very dependent on how much is burning, how far from the fire the measurement is made, variations within the plume, weather conditions, effects of the surroundings, etc. In other word, how representative the sampling and measurements are can sometimes be questioned. One example of results from analyses in conjunction with real tyre fires has been reported by Reisman et al. who present VOC results from a number of fires [19]. There are, however, significant variations between the results.

One problem in connection with tyre fires is that pyrolysis oil is produced and this oil can contaminate the ground and follow the runoff water to watercourses. During the fire in Hagersville in Canada [20], samples of such oil were taken and analysed [22]. Dioxins were found but no specific conclusions were drawn and it is difficult to relate the results to a certain amount of consumed tyres.

A number of small scale fire tests with tyre material have been performed [19, 23-25] [26]. These test series include a large number of analyses and measurements and therefore also much interesting information. It should, however, be noted that not only the scale is different from real scale storage situation; also the types of pieces used and the availability of oxygen might vary. It is, therefore, of interest possible to see how these factors influence the results.

Based on several factors: the increased number of temporary storage depots and thereby the increased risk for fires; the question of how, for example, the type of storage influences the emissions from a certain type of fire, the increasing awareness of the importance of fires' contribution to total emissions, etc., it was decided to perform a research project aimed at studying the entire course of events from a certain fire scenario, via the production of emissions transported in the fire plume, and spread of emissions to the final distribution of emitted substances in the air, soil, and water [27, 28]. 
The result has been the development of a methodology to study the environmental impact of fires, with a number of different subparts. These subparts include: a description and modelling of the fire scenario, modelling of the production of emissions, and modelling of spread of emissions and contaminant fate. The project is presented in a project report describing the methodology, the subparts, and main conclusions [27]. Detailed information on the subparts can be found in separate reports [29-33].

Two different scenarios for fires in temporary stored goods before recycling, dismantling or combustion of used products were selected, i.e., electrical and electronics waste (EE waste) and used tyres. Used products of these two types are collected in large amounts each year in Sweden. As discussed above, there are many examples of fires in landfills or storages with tyres, both internationally and from Sweden. Fires in tyres distinguish themselves in that they are difficult to extinguish and exhibit incomplete combustion leading to large amounts of emissions. There is very little information available on fires in EE waste, but with the increasing amount of EE products used, this is a product group that is interesting to study due to the increasing potential for fires in such waste storage.

Medium scale tests were performed with EE waste and tyres in the fire hall of SP Fire Technology [29, 30]. The fuel was comprised of used goods collected in Sweden for recycling. Four tests with each type of fuel were performed. In the tests with EE waste, $242 \mathrm{~kg}$ of products was used with the same distribution of TVs, computers, vacuum cleaner, etc. as are usually collected. Products were selected from a large amount of waste to give the same composition of products in each test. The EE-waste was placed in the same type of cages that are used for collection and recycling of EE-waste in Sweden (see Figure 2). During the test series with EE-waste, the set-up was varied. In two tests water application was used to be able to analyse runoff water and in one test the sides of the cage was covered with steel plates to limit access of air. The test series is described in Table 1.
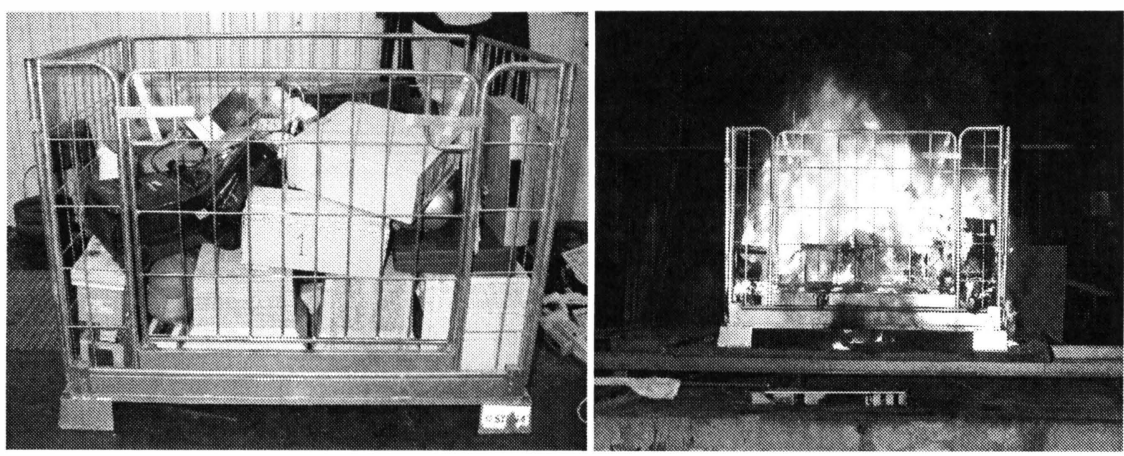

Figure 2. Experimental set-up with EE-waste in a cage.

In the tests with car tyres, 32 tyres $(240-250 \mathrm{~kg})$ were used in each test. The test set-up was varied in this case also. In three of the tests, the tyres were placed in a large heap (see Figure 3), while in one test the tyres were placed in four piles with eight tyres in each pile. In two of the heap tests water application was used. In one of these cases foam solution was 
added to the water (see Table 1 for description of the test series). A special water applicator with nine nozzles was designed to control but not extinguish the fire.
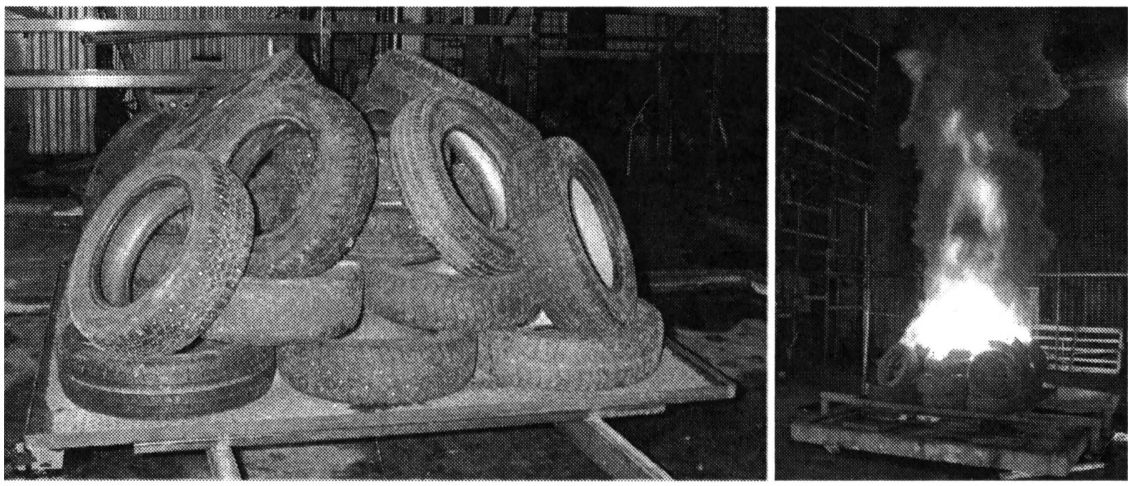

Figure 3. Experimental set-up with tyres placed in a heap.

Table1. Experimental set-up with tyres placed in a heap.

\begin{tabular}{cccc}
\hline Test id & Type of fuel & Description & Mass $(\mathrm{kg})$ \\
\hline T1 & EE-waste & No water application; no steel plates & 242.4 \\
\hline T2 & EE-waste & Water application; no steel plates & 242.4 \\
\hline T3 & EE-waste & No water application; steel plates & 242.4 \\
\hline T4 & EE-waste & Water application; no steel plates & 242.4 \\
\hline T5 & Tyres & 32 tyres in a heap; no water application & 245.6 \\
\hline T6 & Tyres & 32 tyres in a heap; water application & 247.0 \\
\hline T7 & Tyres & 32 tyres in a heap; water/foam application & 239.2 \\
\hline T8 & Tyres & 32 tyres in a heap (8 in each pile); no water \\
& & application & 245.9 \\
\hline
\end{tabular}

During and after the tests, fire gases, run-off water, and fire debris were analysed, e.g. for inorganic gases, volatile organic compounds (VOC), polycyclic aromatic hydrocarbons (PAH), polychlorinated dibenzodioxins/furans (PCDD/PCDF), polybrominated dibenzodioxins/furans (PBDD/PBDF), selected brominated flame retardants, particles, and metals.

As a general conclusion one can say that the application of water increases the yields of organic species. This is the case for VOC, PAH, PCDD/PCDF, PBDD/PBDF, and brominated flame retardants. Examples of results are given in Figure 4 (EE-waste) and Figure 5 (tyres) where yields of PAH in the fire gases are presented. Note the different scales in the two figures.

The yield of PCDD/PCDF (TCDD I-TEQ) varied between 0.99 and $16.6 \mu \mathrm{g} / \mathrm{kg}$ for the tests with EE-waste, which is much higher than the yield from landfill fires reported above. 
As mentioned above, the decision to use stored EE-waste as one of the fuels in the presented research project was based on estimated risks rather than on any specific fire involving EEwaste. It is, therefore, interesting to note that in June 2007 there was a fire in a recycling company handling EE-waste. The investigation of the fire has not been completed, but a comparison between the analysed runoff water from the fire and the runoff water from the fire tests described above show that the results (PAH, PCDD/PCDF, and metals) are similar to each other, e.g., the results of the sum of seven carcinogenic PAHs, which was $0.018 \mathrm{mg} / \mathrm{L}$ in the water from the fire and $0.034 \mathrm{mg} / \mathrm{Lein}$ the water from the fire test (T4). For PCDD/PCDF (TCDD I-TEQ) the values were $0.24 \mathrm{ng} / \mathrm{L}$ and $0.86 \mathrm{ng} / \mathrm{L}$, respectively. In general the analysis values from the real fire are somewhat lower, but one should remember that there are several parameters affected the concentration, e.g. how and how much water is applied and where the samples are taken.

From these comparison, two conclusions can be drawn: 1) fires in EE-waste produce a large number of different types of emissions, both to air and in the runoff water and 2) the medium scale fire tests can be said to be representative of real fire (at least regarding the runoff water).This is an important conclusion since this type of test can be used to predict emissions from different types of fires.

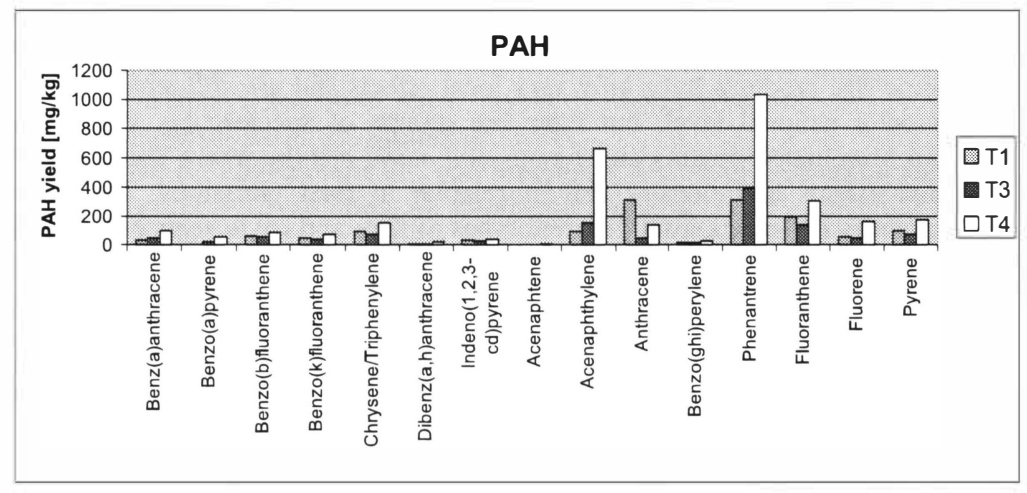

Figure 4. Yield of PAH in the fire gases from EE-waste.

\section{DISCUSSION AND CONCLUSIONS}

In this paper examples of emissions from different types of waste have been given. The presentation of the data is not exhaustive but it aims to show that the large number of temporary storage depots that are a result of the recycling of waste can lead to increased fire risk and to large emissions if involved in a fire. This needs to be considered when planning a new storage site or when deciding on how to configure a certain storage depot.

The examples of fires or fire tests given in this paper have been chosen either due of the size of the fire or because of the possibility of calculating yields of different species from the results. To have good analyses for different types of fires is very important when trying to 
reduce environmental risks from a certain type of storage during the planning phase, and to have basis for correct decision making during a fire.

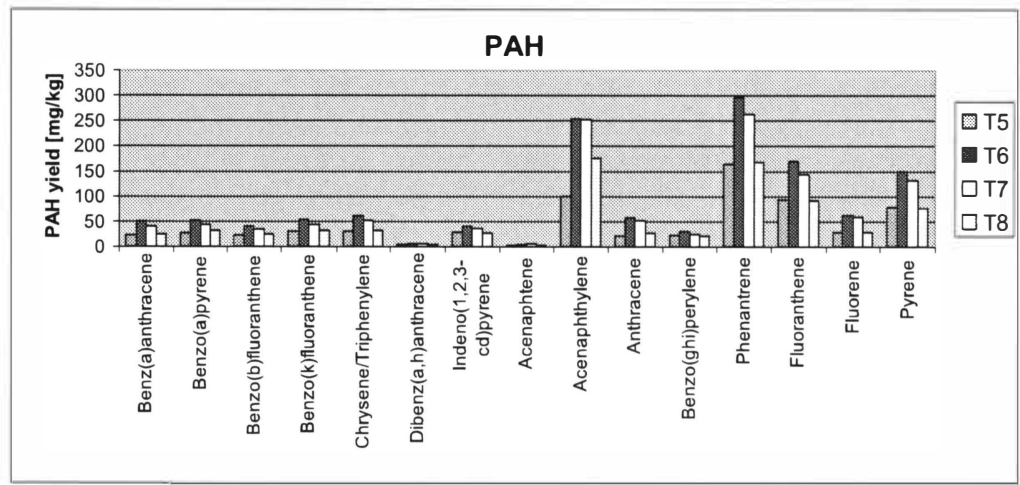

Figure 5. Yield of PAH in the fire gases from tyres.

As the restriction of emissions, e.g from controlled combustion, have led to better control of certain sources of emission, the emissions from fires have become even more important than previously. Some fire products have only very local effects and are still small compared to other sources on a national level, but there are groups of species, e.g. PAH, particles, chlorinated and brominated dioxins and furans, and some metals, where the emissions can have significant effects both locally and in relation to total emissions. Therefore it is important to quantify emissions from different types of fires and try to reduce the probability for a fire and the effects of a fire should it start.

\section{ACKNOWLEDGEMENT}

Several of the experiments presented in this paper were financed by SRV, the Swedish Rescue Service Agency, which is gratefully acknowledged.

\section{REFERENCES}

[1] "Council Directive 1999/31/EC of 26 April 1999 on the landfill of waste", In Official Journal of the European Communities, 1999.

[2] SFS 2001:512, "Förordning om deponering av avfall", 2001.

[3] Hogland, W., Nammari, D., Sandstedt, K., Stenis, J., "Brandei lagrat avfallsbränsle hos Cemmiljö A/S i Ålborg", RVF - Svenska Renhållningsverksföreningen, RVF:s Utvecklingssatsning Deponering, Rapport nr 6, Malmö, 2006.

[4] Pettersson, K., Boström, C.- §., Antonsson, A.-B., "Bränder på avfallsupplag Mätningar av luftföroreningar $\mathrm{i}$ arbetsmiljön och emissioner till den yttre miljön $\mathrm{i}$ samband med släckning av tippbränder", IVL Institutet för Vatten- och Luftvårdsforskning, IVL Rapport B 1211, Stockholm, Sweden, 1996.

[5] Ettala, M., Rahkonen, P., Rossi, E., Mangs, J., Keski-Rahkonen, O., "Landfill Fires in Finland", Waste Management \& Research, 14, 377-384, 1996.

[6] Öhrström, T., "Tester för simulering av bränder på avfallsupplag", Miljökonsulterna, MKS-89/96, Studsvik, 1989. 
[7] Lönnermark, A., Blomqvist, P., Marklund, S., "Emissions from Simulated Deep-Seated Fires in Domestic Waste", Chemosphere, Accepted for publication.

[8] Nammari, D. R., Hogland, W., Marques, M., Nimmermark, S., and Moutavtchi, V., "Emissions from a controlled fire in municipal solid waste bales", Waste Management, 24, 9-18, 2004.

[9] Ruokojärvi, P., Ruuskanen, J., Ettala, M., Rahkonen, P., and Tarhanen, J., "Formation of Polyaromatic Hydrocarbons and Polychlorinated Organic Compounds in Municipal Waste Landfill Fires", Chemosphere, 31, 8, 3899-3908, 1995.

[10] Lemieux, P. M., "Evaluation of Emissions From the Open Burning of Household Waste in Barrels", EPA, EPA-600/R-97-134a, 1997.

[11] Lemieux, P. M., Gullett, B. K., Lutes, C. C., Winterrowd, C. K., and Winters, D. L., "Variable Affecting Emissions of PCDD/Fs from Uncontrolled Combustion of Household Waste in Barrels", Air \& Waste Manage, 53, May 2003, 523-531, 2003.

[12] Lemieux, P. M., Lutes, C. C., Abbott, J. A., and Aldous, K. M., "Emissions of Polychlorinated Dibenzo-p-dioxins and Polychlorinated Dibenzofurans from the Open Burning of Household Waste in Barrels", Environmental Science \&Technology, 34, 3, 377-384, 2000.

[13] Gullett, B. K., Lemieux, P. M., Lutes, C. C., Winterrowd, C. K., and Winters, D. L., "Emissions of PCDD/F from uncontrolled, domestic waste burning", Chemosphere, 43, 721-725, 2001.

[14] Rosén, B., Carling, M., Nilsson, G., and Nilsson, M., "Utsläpp i samband med olyckor - Metodutveckling av provtagning vid räddningstjänst", Räddningsverket, P21-392/01, Karlstad, 2001.

[15] SGI, "Utsläpp i samband med olyckor: Metodutveckling av provtagning vid räddningstjänst - Etapp 2", Räddningsverket.

[16] Blomqvist, P., Lönnermark, A., and Simonson, M., "Miljöbelastning vid bränder och andra olyckor - Utvärdering av provtagning och analyser", Räddningsverket, P21452/04, Karlstad, Sweden, 2004.

[17] "Tire Fires", U.S. Environmental Protection Agency, http://www.epa.gov/epaoswer/non-hw/muncpl/tires/fires.htm, 2 December 2003.

[18] Yamaguchi, E., "Emissions from Open Tire Fires", http://www.p2pays.org/ref/11/10504/html/intro/openfire.htm, 13 October 2000.

[19] Reisman, J. I., "Air Emissions from Scrap Tire Combustion", United States Environmental Protections Agency, EPA-600/R-97-115, 1997.

[20] "Tyre fires - a pile of polution", Fire Prevention, 241, July/August, 22-26, 1991.

[21] Steer, P. J., Tashiro, C.eH. M., Mclllveen, W. D., and Clement, R. E., "PCDD and PCDF in Air, Soil, Vegetation and Oily Runoff from a Tire Fire", Water, Air and Soil Pollution, 82, 659-674, 1995.

[22] Thompson, T. S., Kolic, T. M., Townsend, J. A., and Mercer, R. S., "Determination of Polychlorinated Dibenzo-p-dioxins and Dibenzofurans in Tire Fire Runoff Oil", Journal of Chromatography, 648, 613-219, 1993.

[23] Lemieux, P. M., and DeMarini, D., "Mutagenicity of Emissions from the Simulated Open Burning of Scrap Rubber Tires", U.S. Environmental Protection Agency, Control Technology Center, office of Research and Development, EPA-600/R-92-127, 1992.

[24] Lemieux, P. M., and Ryan, J. V., "Characterization of Air Pollutants Emitted from a Simulated Scrap Tire Fire", Journal of the Air \& Waste Management Association, 43, 1106-1115, 1993. 
[25] Lemieux, P. M., Lutes, C. C., and Santoianni, D. A., "Emissions of organic air toxics from open burning: a comprehensive review", Progress in Energy and Combustion Science, 30, 1-32, 2004.

[26] Büthe, N., "Combustion of efluents rubber", http://www.buethe.onlinehome.de/research.htm.

[27] Lönnermark, A., Andersson-Sköld, Y., Axelsson, J., Haeger-Eugensson, M., Palm Cousins, A., Rosén, B., and Stripple, H., "Emissioner från bränder - Metoder, modeller och mätningar", Räddningsverket, P20-470/07, Karlstad, 2007.

[28] Lönnermark, A., Stripple, H., Rosén, B., Haeger-Eugensson, M., Axelsson, J., Andersson-Sköld, Y., Palm Cousins, A., and Simonson, M., "Emissions from Fires Methods, Models and Measurements", Proceedings og the 11 th International Fire Science \& Engineering Conference (Interflam 2007), 1625-1630, London, UK, 3-5 September, 2007.

[29] Lönnermark, A., and Blomqvist, P., "Emissions from Fires in Electrical and Electronics Waste", SP Swedish National Testing and Research Institute, SP REPORT 2005:42, Borås, Sweden, 2005.

[30] Lönnermark, A., and Blomqvist, P., "Emissions from Tyre Fires", SP Swedish National Testing and Research Institute, SP REPORT 2005:43, Borås, Sweden, 2005.

[31] Lönnermark, A., Stripple, H., and Blomqvist, P., "Modellering av emissioner från bränder", SP Sveriges Provnings- och Forskningsinstitut, SP Rapport 2006:53, Borås, 2006.

[32] Haeger-Eugensson, M., Tang, L., Chen, D., Axelsson, J., Lönnermark, A., and Stripple, H., "Spridning till luft från bränder", IVL Svenska Miljöinstitutet, IVL rapport B-1702, Göteborg, 2006.

[33] Rosén, B., Andersson-Sköld, Y., and Starzec, P., "Emissioner från bränder - Spridning till mark och vatten", Statens geotekniska institut, SGI Varia nr 568, Linköping, 2006. 